\title{
Effect of dietary fiber on the bioaccessibility of phenolic compounds of mango, papaya and pineapple fruits by an in vitro digestion model
}

\author{
Gustavo VELDERRAIN-RODRÍGUEZ', Ana QUIRÓS-SAUCEDA', Gil MERCADO-MERCADO², \\ Jesús Fernando AYALA-ZAVALA ${ }^{1}$, Humberto ASTIAZARÁN-GARCÍA ${ }^{1}$, Rosario Maribel ROBLES-SÁNCHEZ ${ }^{3}$, \\ Abraham WALL-MEDRANO ${ }^{4}$, Sonia SAYAGO-AYERDI ${ }^{2}$, Gustavo Adolfo GONZÁLEZ-AGUILAR ${ }^{1 *}$
}

\begin{abstract}
The presence of dietary fiber (DF) in the food matrix of some tropical fruits plays an important role in the release and absorption of its bioactive compounds, such as phenolic compounds (PCs). The aim of this study was to evaluate the effect of the DF fractions in mango cv. 'Ataulfo', papaya cv. 'Maradol' and pineapple cv. 'Esmeralda', on the bioaccessibility of their PCs and antioxidant capacity (AOXC) under an in vitro digestion model. The highest PCs content and AOXC was found in mango (274.30 mg GAE/100 g FW), followed by papaya (212 mg GAE//100 g FW), and pineapple (107.63 mg GAE/100 g FW), respectively. About $50 \%$ of the total PCs in all fruits was released at gastric phase, increasing closer to $60 \%$ at intestinal phase in mango and pineapple. However, the highest content of PCs associated to DF was found in mango (2.48 mg GAE/100 g FW) compared with papaya DF fractions $(0.96 \mathrm{GAE} / 100 \mathrm{~g} \mathrm{FW})$ and pineapple $(0.52 \mathrm{GAE} / 100 \mathrm{~g} \mathrm{FW})$. The presence of DF in mango, papaya and pineapple did not represent a major limitation on the bioaccessibility of its PCs according to the in vitro digestion model used in this study.
\end{abstract}

Keywords: tropical fruit; phenolic compounds; antioxidant capacity; dietary fiber; bioaccessibility; in vitro digestion.

Practical Application: Impact of dietary fiber on the release and absorption of bioactive compounds.

\section{Introduction}

Currently, consumers are concerned about maintaining a certain balance between their health and nutrition (Ragaert et al., 2004). Plenty of studies have shown that plant origin foods are important sources of bioactive compounds, also known as phytochemicals (Dembitsky et al., 2011a, b; Gayosso-García Sancho et al., 2011; Hossain \& Rahman, 2011; Nohynek et al., 2006). Among the most common bioactive compounds occurring in plant origin foods are phenolic compounds (PCs), carotenoids, xanthophylls, and chlorophylls, among others (Hossain \& Rahman, 2011). Tropical fruits are considered as a rich source of antioxidants and bioactive compounds, mostly PCs. However, as it has been reported in several studies, the common extraction methods using solvents do not allow the complete extraction of PCs (Escarpa \& González, 2001; Kristl et al., 2011). Hence, there has been a classification of PCs according their ease of extraction: extractable (EPC) and non extractable (NEPC) (Bravo, 1998). Tropical fruits are plenty and diverse, and recent research suggests that an appropriate consumption of them may confer different health benefits (Das et al., 2012; Leifert \& Abeywardena, 2008; Nohynek et al., 2006). These compounds can also have antioxidant capacity (AOXC) and protect against oxidative stress in different body tissues, if they are adequately released from the food matrix and absorbed in the small intestine (Palafox-Carlos et al., 2011).
Bioaccessibility and bioavailability are terms involved with the release and absorption of nutrients, vitamins, PCs, and other components from food matrices (Porrini \& Riso, 2008). Bioaccessibility refers to the proper release of nutrients or specific bioactive compounds within the food matrix due to the conditions of the gastrointestinal tract (Saura-Calixto et al., 2007). Moreover, bioavailability represents the total amount that is released and absorbed, reaching the bloodstream, where they are delivered to the different body tissues (Manach et al., 2005). Therefore, the association or interaction of PCs with other food matrix components could affect both bioaccessibility and bioavailability of PCs (Manach et al., 2004). In this context, it's important to point out that tropical fruits possess matrices rich in $\mathrm{DF}$, and it has been proven that different molecular interactions with PCs occurred and bioaccessibility is negatively affected (Bouayed et al., 2011; Palafox-Carlos et al., 2011). Tropical fruits contain different types and amounts of DF, therefore these differences could affect the type of interaction and kinetic release of PCs from food matrix.

Various studies have shown that the interaction between DF and PCs could be related to non-covalent bonds as electrostatic forces and hydrogen bonds as Van der Waals forces (PalafoxCarlos et al., 2011). This linkage is formed between the available hydroxyl groups of PCs and the diverse components of DF

Received 19 Aug., 2015

Accepted 20 Jan., 2016

${ }^{1}$ Coordinación de Tecnología de Alimentos de Origen Vegetal, Centro de investigación en Alimentación y Desarrollo - CIAD, Hermosillo, Sonora, México

${ }^{2}$ Instituto Tecnológico de Tepic - ITT, Nayarit, México

${ }^{3}$ Universidad de Sonora - UNISON, Hermosillo, Sonora, México

${ }^{4}$ Instituto de Ciencias Biomédicas, Universidad Autónoma de Ciudad Juárez - UACJ, Ciudad Juárez, Chihuahua, México

*Corresponding author: gustavo@ciad.mx 
(Nantitanon et al., 2010; Palafox-Carlos et al., 2011; Porrini \& Riso, 2008). Since the AOXC of PCs is attributed to the number and localization of their hydroxyl groups, their interaction with DF could not only limit their absorption, but it also prevents these groups from stabilizing free radicals (Palafox-Carlos et al., 2011). However, PCs can be covalently bound to complex polysaccharides in cell walls of food matrices, such as ferulic acid bound to arabinoxylans in wheat bran (Anson et al., 2009). These bonds limit the bioaccessibility, and consequently lowering the antioxidant activity due to the lower hydroxyl groups available to stabilize radicals. In this context, the objective of this study was to evaluate the effect of the DF within the food matrix of different tropical fruits on the bioaccessibility of PCs and its AOXC under in vitro simulated conditions of the gastrointestinal tract.

\section{Materials and methods}

\subsection{Fruit material}

Fruits at commercial ripeness stage were purchased from a local supermarket in Hermosillo, Sonora, Mexico. Fruits were selected for their differences in dietary fiber content, the selected fruits being: pineapple cv. 'Esmeralda', mango cv. 'Ataulfo' and papaya cv. 'Maradol'. The pulp of each fruit was lyophilized and storage for further analysis.

\subsection{Extraction and quantification of total phenolic compounds}

Total PCs is given by the sum of extractable (EPCs) and non-extractable PCs (NEPCs). EPCs were extracted according to Pérez-Jiménez \& Saura-Calixto (2005), with some modifications. $0.5 \mathrm{~g}$ of sample was first homogenized with methanol-water acidified with $\mathrm{HCl}(50: 50 \mathrm{v} / \mathrm{v}, 1 \mathrm{~h}$, constant shaking), and later with acetone-water $(70: 30 \mathrm{v} / \mathrm{v}, 1 \mathrm{~h}$, constant shaking). After centrifugation $\left(211 \mathrm{~g} 4^{\circ} \mathrm{C}, 10 \mathrm{~min}\right)$, the supernatants were collected and the precipitate was washed two more times under the conditions previously described. The two supernatants were combined, filtered and made up to a final volume of $50 \mathrm{~mL}$. EPCs were quantified by the Folin-Ciocalteu method described for Singleton \& Rossi (1965) and results were expressed as mg of gallic acid equivalents (GAE)/100 g of fresh weight (FW).

The content of NEPCs (strongly associated with the food matrix) was performed following the modified method described by Hartzfeld et al. (2002). NEPCs are divided into hydrolyzable (HT) and condensed tannins (CT). The method for the extraction of HT and CT consisted in the hydrolysis of the residues obtained from the EPC. The HT were extracted using a methanol:sulfuric acid $(10: 1 \mathrm{v} / \mathrm{v})$ solution for $20 \mathrm{~h}$ at $85^{\circ} \mathrm{C}$; whereas CT were extracted using $\mathrm{HCl}-\mathrm{Butanol}$ for $3 \mathrm{~h}$ at $100^{\circ} \mathrm{C}$. The HT were measured by the Folin-Ciocalteu method and expressed as GAE)/100g of FW; whereas CT were expressed using a standard curve from carob pod (Ceratonia siliqua).

\subsection{Antioxidant capacity evaluation assays}

The AOXC of samples was measured according to the DPPH (2,2-diphenyl-1-picrylhydrazyl) and TEAC (Trolox Equivalence Antioxidant Capacity) assays. The DPPH assay was performed according to Brand-Williams et al. (1995) with some modifications. The stock solution was prepared by mixing $2.5 \mathrm{mg}$ of DPPH radical with $100 \mathrm{~mL}$ of methanol. The absorbance of the solution was adjusted to $0.7 \pm 0.02$ at $515 \mathrm{~nm}$. The reaction was done in a Costar 96 microplate by adding $280 \mu \mathrm{L}$ of the adjusted radical to $20 \mu \mathrm{L}$ of sample. The mixture was kept in darkness for $30 \mathrm{~min}$, followed by reading the absorbance at $515 \mathrm{~nm}$ with a microplate reader Synergy HT (Biotek ${ }^{\circledast}$, USA). The results were expressed as mg of Trolox Equivalents (TE)/100g of FW.

The TEAC assay was performed according to the methodology described by Re et al. (1999). This method is based on the discoloration of the stock solution of ABTS radical due to its reduction in the presence of antioxidant compounds. The absorbance of the stock solution was adjusted to $0.7 \pm 0.02$ at $762 \mathrm{~nm}$ based on previous the sample addition. The mixture was kept in darkness for $5 \mathrm{~min}$, followed by absorbance readings at $762 \mathrm{~nm}$ using a microplate reader Synergy HT (Biotek ${ }^{\oplus}$, USA). The reaction was conducted in a Costar96 microplate with the addition of $245 \mu \mathrm{L}$ of the adjusted radical to $5 \mu \mathrm{L}$ of sample. The results were expressed as mg of TE/100 $\mathrm{g}$ of FW.

\subsection{Total dietary fiber content and associated phenolic compounds}

The evaluation of total DF content in the tropical fruit pulps, as well as the soluble and insoluble fractions, were determined according to the method described by Mañas \& Saura-Calixto (1995), with some modifications. The modification of this method is based on the use of dialysis bags replacing the precipitation with ethanol. After enzymatic hydrolysis of the samples, they were separated in soluble DF fraction (SDF) and insoluble DF fraction (IDF). The IDF was quantified gravimetrically before its hydrolysis with sulfuric acid for Klasson Lignin (KL) determination. The total IDF was calculated as the sum of the insoluble fraction (IF) and KL ( $\sum$ total IF= IF+ KL). On the other hand, the SDF was hydrolyzed with $1 \mathrm{M}$ sulfuric acid $\left(100^{\circ} \mathrm{C}, 90 \mathrm{~min}\right)$, for total carbohydrate determination by 3,5 dinitrosalicylic acid (DNS) method (Borel et al., 1952). The total DF was considered to be the sum of both fractions, and expressed as percentage on dry basis. The associated phenolic compounds (APC) of either SDF or IDF were measured by the Folin-Ciocalteu method as described by Singleton \& Rossi (1965). The results of APC were expressed as mg of gallic acid equivalents (GAE)/100g of fresh weight $(\mathrm{FW})$.

\subsection{In vitro digestion}

The simulation of the digestion conditions of the gastrointestinal tract was done according to Saura-Calixto et al. (2000), with some modifications. In this method, the sample underwent three simulated digestion phases: gastric, intestinal and starchy carbohydrates digestion. The gastric phase conditions were done simulating the acidic conditions of the stomach. $300 \mathrm{~g}$ of sample with $10 \mathrm{~mL}$ of $\mathrm{HCl}-\mathrm{KCl}$ buffer ( $\mathrm{pH} \mathrm{1.5)}$ were incubated with pepsin (Sigma P-700) solution $\left(300 \mathrm{mg} / \mathrm{mL}\right.$ ) for $1 \mathrm{~h}$ at $40^{\circ} \mathrm{C}$ in a water bath with constant shaking. After this point, the gastric phase was concluded and samples of the solution were taken for further analysis. The intestinal phase was simulated as previously described above. After hydrolysis with pepsin, the samples were 
incubated for $6 \mathrm{~h}$ at $37^{\circ} \mathrm{C}$ in a water bath with constant shaking by addition of $4.5 \mathrm{~mL}$ of Phosphate buffer $(\mathrm{pH} 7.5)$ and $1 \mathrm{~mL}$ of pancreatin (Sigma P-1750) solution $(5 \mathrm{mg} / \mathrm{mL}$ ). Then, $9 \mathrm{~mL}$ of tris-Maleate buffer $(0.1 \mathrm{M}, \mathrm{pH} 6.9)$ was added. An aliquot of sample was taken for its subsequent analysis. The digestion phase of starchy carbohydrates included the steps mentioned above, followed by the subsequent addition of $9 \mathrm{~mL}$ of tris-maleate buffer ( $\mathrm{pH}$ 6.9) and pancreatic $\alpha$-amylase (Sigma A-31176) $\left(37^{\circ} \mathrm{C}, 16 \mathrm{~h}\right)$, to hydrolyze the remaining starch that may have withstood the above conditions. Finally, samples were taken at this phase for further analysis. All samples collected were stored at $-20^{\circ} \mathrm{C}$ until the analysis of total PCs content and AOXC was conducted.

\subsection{Statistical analysis}

The analysis of results was performed with a completely randomized design considering the digestion phases (gastric, intestinal, and starchy carbohydrate) as factors. The comparison between the total PCs content and the AOXC of the fruits was performed using an ANOVA with a 95\% confidence through the statistical package NCSS 2007.

\section{Results and discussion}

\subsection{Total phenolic compounds and antioxidant capacity}

Total PCs content and the AOXC of the fruits are shown in Figure 1. The CT were not detected in the studied fruits. In the absence of CT, we found that the total PCs could be considered as the sum of the EPCs and the HT. The results

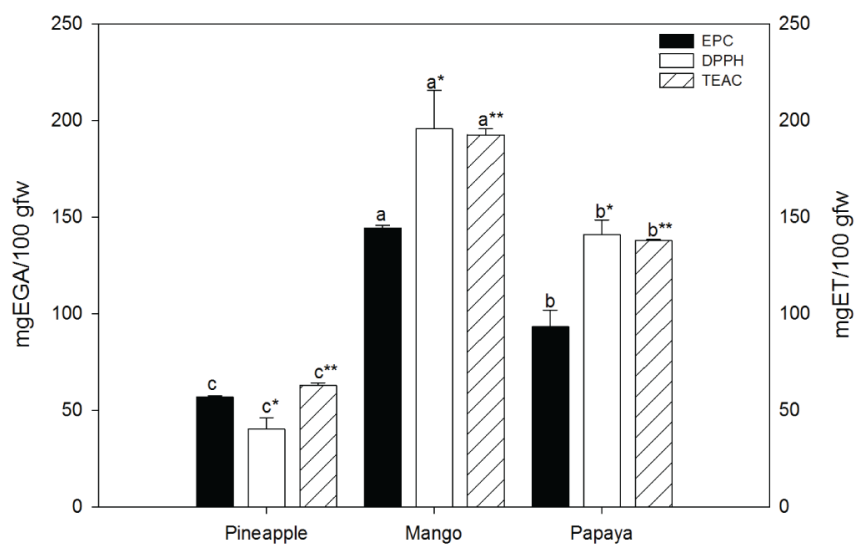

Figure 1. EPC content and AOXC of tropical fruits. Data are means of at least three determinations $(n=3) \pm$ the standard deviation. Different letters within the bars sharing the same symbol $\left(^{*}\right)$ indicate significant differences $(p \leq 0.05)$. indicated that the fruit with higher content of EPCs was mango cv. with $144.34 \pm 1.37 \mathrm{mg} \mathrm{GAE} / 100 \mathrm{~g} \mathrm{FW}$, followed by papaya and pineapple $\mathrm{cv}$. with $93.18 \pm 8.66$ and $56.83 \pm 0.60 \mathrm{mg}$ GAE/100 g FW, respectively. Most of the literature about PCs in these fruits, as well as in many other plant foods, considered the EPCs as the total phenolics, underestimating the content of NEPCs (Arranz et al., 2009; Mertz et al., 2009; Palafox-Carlos et al., 2012a). The NEPCs are represented by HT and CT, or those PC with higher molecular weight associated to DF or protein within the food matrix (Arranz et al., 2009). The results obtained are similar to those reported by Palafox-Carlos et al. (2012b), Gayosso-García Sancho et al. (2011) and Hossain \& Rahman (2011) for these types of fruits.

The EPCs values found in these fruits were consistent with the AOXC, with mango pulp having the higher values (194.69 mg TE/100 g FW in DPPH assay, and $192.53 \mathrm{mg}$ TE/g FW in TEAC assay). Mango AOXC values were followed by those found in papaya (140.98 and $197.86 \mathrm{mg} \mathrm{TE} / 100 \mathrm{gfw}$ ) and pineapple (40.29 and $62.87 \mathrm{mg}$ TE/100 gfw) DPPH and TEAC values, respectively. On the other hand, as was mentioned previously, the TPC content in pulp is considered as the sum of EPC and NEPC. In this case, just HT as it is shown in Table 1. These results, demonstrated that the content of HT in fruit pulps is comparable to the EPC content, reasserting that nearly half of the content of TPC in these fruits has been underestimated in other studies (Gayosso-García Sancho et al., 2011; Hossain \& Rahman, 2011; Palafox-Carlos et al., 2012a). Nevertheless, the TPC remains in the same order, with the higher content of TPC in mango (274.30 mg GAE/100 g FW), followed by papaya (212.17 mg GAE/100 g FW) and pineapple (107.63 GAE/100 g FW).

\subsection{Dietary fiber content and associated phenolic compounds}

The results of the SDF, IDF, KL and total DF content in mango, papaya and pineapple are presented in Table 2. The total DF content did not differ $(p>0.05)$ between mango and papaya; however, this difference is significant when they are compared with pineapple. These results show that papaya fruit has a higher DF content with IDF and SDF values of 7.09\% and $1.8 \%$, respectively. On the other hand, mango and papaya showed similar percentages of IDF having $2.64 \%$ and $2.91 \%$ IDF, respectively. These values are similar to those reported by Quirós-Sauceda (2012), who found that fruits like pineapple and guava are rich sources of IDF. There were significant differences $(p<0.05)$ between the SDF contents of the fruits, papaya being the one with higher SDF content (2.91\%), followed by mango (2.64\%) and pineapple (1.82\%). These results are similar to those reported by Ramulu \& Rao (2003) who reported similar amounts

Table 1. Total extractable and non-extractable phenolic compounds content of tropical fruits.

\begin{tabular}{crrrr}
\hline Tropical fruit & EPC & HT & CT & TP \\
\hline Pineapple & $56.83 \pm 0.60 \mathrm{c}$ & $50.79 \pm 0.65 \mathrm{~b}$ & Nd & $107.63 \pm 1.01 \mathrm{c}$ \\
Mango & $144.34 \pm 1.37 \mathrm{a}$ & $129.95 \pm 8.41 \mathrm{a}$ & Nd & $274.30 \pm 9.32 \mathrm{a}$ \\
Papaya & $93.18 \pm 8.66 \mathrm{~b}$ & $118.98 \pm 3.92 \mathrm{a}$ & Nd & $212.17 \pm 2.40 \mathrm{~b}$ \\
\hline
\end{tabular}

Data are means of at least three determinations $(n=3) \pm$ standard deviation. Different letters within the same column indicates significant differences $(p \leq 0.05)$. Nd $=$ not detected.

The total phenolic content indicates the sum of the total extractable and HT. Values are expressed as mg equivalents of gallic acid/100g fresh weight. EPC = Extractable Phenolic Compounds HT = Hydrolyzable Tannins; $\mathrm{CT}=$ Condensed Tannins; $\mathrm{TP}=$ Total Phenolics. 
of SDF in papaya and mango, but lower values in pineapple SDF. The presence of KL was not detected in the pulp of these fruits studied because this DF component is mainly found in the fruit skin (Femenia et al., 1998). The KL represents the lignin value obtained gravimetrically based on their solubility in acid (Quintana et al., 2008).

Recent studies have shown that the addition of DF to PCs solutions of tropical fruits decreased AOXC (Quirós-Sauceda et al., 2014). This reduction ranges from 5 to $21 \%$ in AOXC by DPPH assay with the addition of DF of the fruit, to a reduction of $23-45 \%$ with a decrease of DF from wheat bran. This indicates that the possible interactions between DF and PCs causes entrapment that does not allow to the hydroxyl groups (present in PCs) to make contact with free radicals found in the medium. Additionally, the presence of large amounts of DF in foods and their possible interactions, prevent its proper absorption in the small intestine (Pérez-Jiménez et al., 2009). The decrease in the absorption of bioactive compounds in the small intestine, limit their biological functions in the body, whereas the antioxidant environment in colon increases (Kanazawa, 2011; Manach et al., 2005; Singhet al., 2008).

Table 3 shows the associated PCs values of the total DF and its fractions (SDF and IDF). According to Saura-Calixto (1998) the DF in the fruits studied cannot be considered as antioxidant. For DF to be considered as antioxidant, it must have a phenolic content associated with DF within a range of 50-70\%. An example of this is the results obtained by Saura-Calixto (1998) in skin of a red grape variety, which reported a $60 \%$ content of PCs associated with DF fractions. In this context, the PCs content associated with $\mathrm{DF}$ fractions in these fruits showed low values, ranging from 0.52 to $2.48 \mathrm{mg} \mathrm{GAE} / 100 \mathrm{~g} \mathrm{FW}$. Therefore, these PCs represent values below $1 \%$ of total PCs presented in the fruits. DF fractions of the fruits studied do not meet the requirements to be considered as antioxidant DF. Thus, the highest APC content of DF fractions was found in mango, representing $0.90 \%$ of TPC, followed by papaya and pineapple.

A low PC content in DF indicates that the PCs in the food matrix of these fruits have no direct interaction between them and $\mathrm{DF}$. The literature suggests that PCs associated with DF, mainly occurs between high molecular weight PCs, defined as those being NEPCs (HT and CT) (Bravo, 1998; Pozuelo et al., 2012). In the case of cereals, fruit or some source considered antioxidant DF, the content of the NEPCs significantly exceeds $(5 \mathrm{x})$ the values of EPCs (Fogliano et al., 2011). This information indicated that these tropical fruits do not possess the typical characteristics of the antioxidant DF, since the PCs or their fractions associated with DF are less than $10 \%$ of the total polyphenols and their content of EPCs and NEPCs are comparable.

\subsection{In vitro digestion}

Figure 2 shows the results regarding the content of PCs during the different phases of an in vitro digestion model. These results indicated that the release or bioaccessibility of PCs in these fruits is about $50 \%$ of its total PCs during the gastric digestion; and these are stable in mango and pineapple during the intestinal digestion phases. On the other hand, although there

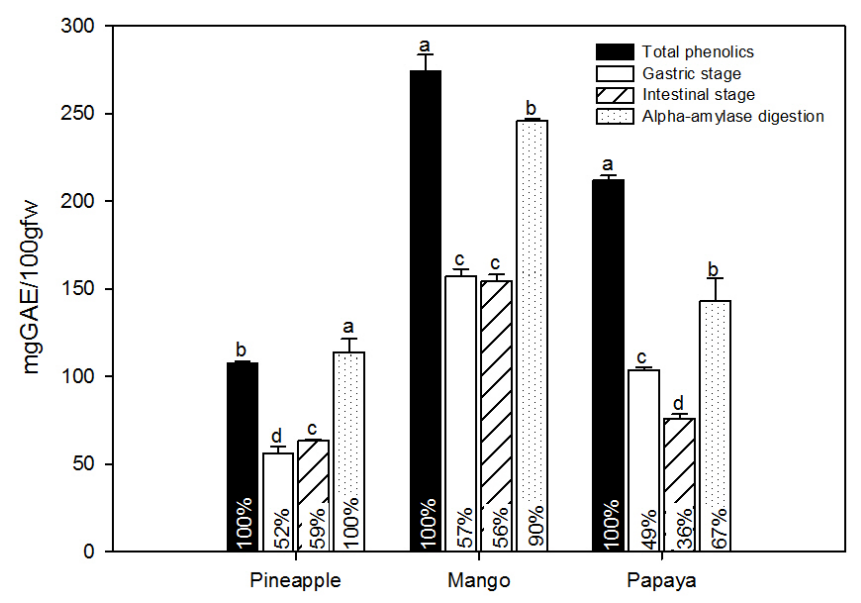

Figure 2. Total phenolic compounds content per fruit in the different stages of simulated digestion in vitro. Data are means of at least three determinations $(\mathrm{n}=3) \pm$ standard deviation. Different letters are assigned to the values of the means by fruits at each phase with significant differences $(\mathrm{p} \leq 0.05)$.

Table 2. TDF fractions and KL content in tropical fruits.

\begin{tabular}{ccccc}
\hline Tropical Fruit & SDF & IDF & KL & TDF \\
\hline Pineapple & $1.82 \pm 0.09 \mathrm{c}$ & $2.35 \pm 0.22 \mathrm{c}$ & Nd & $3.90 \pm 0.50 \mathrm{c}$ \\
Mango & $2.64 \pm 0.04 \mathrm{~b}$ & $3.24 \pm 0.10 \mathrm{~b}$ & Nd & $6.07 \pm 0.34 \mathrm{~b}$ \\
Papaya & $2.91 \pm 0.11 \mathrm{a}$ & $4.37 \pm 0.24 \mathrm{a}$ & Nd & $7.09 \pm 0.11 \mathrm{a}$ \\
\hline
\end{tabular}

Data are means \pm SD of three determinations $(n=3)$. Different letters within the same column indicated significant differences $(p \leq 0.05)$. Nd $=$ not detected. Values are expressed as percentage on dry basis. SDF = Soluble Dietary Fiber; IDF = Insoluble Dietary Fiber; KL = Klasson Lignin; TDF = Total Dietary Fiber.

Table 3. PC content associated with DF fractions of tropical fruits.

\begin{tabular}{cccc}
\hline Tropical Fruit & SDF & IDF & TDF \\
\hline Pineapple & $0.52 \pm 0.02 \mathrm{~b}$ & Nd & $0.52 \pm 0.02 \mathrm{c}$ \\
Mango & $0.96 \pm 0.01 \mathrm{a}$ & $1.51 \pm 0.04 \mathrm{a}$ & $2.48 \pm 0.039 \mathrm{a}$ \\
Papaya & $0.72 \pm 0.03 \mathrm{~b}$ & $0.24 \pm 0.02 \mathrm{~b}$ & $0.96 \pm 0.031 \mathrm{~b}$ \\
\hline
\end{tabular}

Data are means of at least three determinations $(n=3) \pm$ standard deviation. Different letters were assigned to the values of means with significant differences $(p \leq 0.05)$ within the same column. $\mathrm{Nd}=$ not detected. Values are expressed as mg GAE/100g FW. SDF = Soluble Dietary Fiber; IDF = Insoluble Dietary Fiber; TDF = Total Dietary Fiber. 
Table 4. Antioxidant capacity of the phenolic compounds released during the different digestion phases.

\begin{tabular}{cccc}
\hline Tropical Fruit & Phase & DPPH & TEAC \\
\hline & Gastric & $2.25 \pm 0.05 \mathrm{~b}$ & $37.15 \pm 0.85 \mathrm{~b}$ \\
Pineapple & Intestinal & $1.56 \pm 0.11 \mathrm{c}$ & $39.98 \pm 4.07 \mathrm{~b}$ \\
& $\alpha$-amylase & $3.32 \pm 0.01 \mathrm{a}$ & $86.92 \pm 1.93 \mathrm{a}$ \\
\hline \multirow{2}{*}{ Mango } & Gastric & $3.26 \pm 0.12 \mathrm{~b}$ & $44.05 \pm 4.67 \mathrm{c}$ \\
& Intestinal & $2.67 \pm 0.08 \mathrm{c}$ & $36.09 \pm 1.62 \mathrm{~b}$ \\
& $\alpha$-amylase & $7.04 \pm 0.23 \mathrm{a}$ & $35.44 \pm 5.76 \mathrm{a}$ \\
\hline \multirow{2}{*}{ Papaya } & Gastric & $2.13 \pm 0.21 \mathrm{~b}$ & $3.71 \pm 3.71 \mathrm{c}$ \\
& Intestinal & $2.10 \pm 0.18 \mathrm{~b}$ & $48.79 \pm 4.84 \mathrm{~b}$ \\
\hline
\end{tabular}

Data are means of at least three determinations $(n=3) \pm$ standard deviation. Different letters were assigned to the values of means with significant differences $(p<.05)$ between columns.

Values are expressed as $\mathrm{mg}$ of trolox equivalents (TE) per $\mathrm{mL}$ of digestive solution.

was up to $50 \%$ of the total PCs in papaya fruit released at gastric conditions, the intestinal conditions with pancreatin digestion showed a decrease in the PCs concentration, indicating loss of PCs at these conditions. Recent studies revealed that some types of PCs can be unstable to physiologic $\mathrm{pH}$ conditions, suffering irreversible structural changes (Friedman \& Jürgens, 2000; Krook \& Hagerman, 2012). These studies explain how simple PCs in papaya fruit, like caffeic acid, might be unstable to alkaline conditions above pH 7 (Friedman \& Jürgens, 2000). On the other hand, a recent study performed by Bouayed et al. (2011), reveals similar information about the bioaccessibility of PCs within the food matrix of different apple varieties. They found that $50 \%$ or even more of the PCs in apple varieties were released in the gastric stage and in some cases showed slight increases, lower than $10 \%$ when arrived to the intestinal phase. However, their results indicate lack of information about what happened to the percentage of PCs not released during digestion, such as if it is degraded or interacting with food matrix components.

To explain the non-released PCs, our study conducted an additional digestion with pancreatic $\alpha$-amylase. This digestion indicates that about $40 \%$ of the total PCs are embeded within the food matrix, in starchy carbohydrates but not in DF fractions. This information reasserts the results found for the PCs associated with the different DF fractions (Table 3), where the major PCs content was associated with the total DF in these fruits was about $1 \%$. On the other hand, the AOXC was also evaluated during the different simulated digestion phases (Table 4). These AOXC values were congruent with the PCs content found during the different digestion phases. The highest AOXC values were found in the additional digestion phase with pancreatic a-amylase, where the highest percentage of total PCs content was released. However, such associated PCs values, compared to those found for EPCs, might be explained by the presence of other bioactive compounds presented in these fruits, such as vitamins and carotenoids (Gayosso-García Sancho et al., 2011; Leontowicz et al., 2011).

\section{Conclusion}

Based on the results found in this study, it is concluded that the mango cv. 'Ataulfo', papaya cv. 'Maradol' and pineapple cv. 'Esmeralda' fruits, are an important source of both low (EPCs) and high molecular weight (HT) PCs. However, the release or bioaccessibility of the PCs present in these tropical fruits occurs gradually during the different digestion phases in this in vitro digestion model. Despite the various types of DF fractions present in the tropical fruits studied; this is not a limitation to the proper releasing of the PCs present in the food matrix. It was further found that the release of PCs, has a positive correlation with the release of PCs (bioaccessibility) and AOXC of the system. Furthermore, it was observed that the effect of trapping of PCs by DF was low, where less than $1 \%$ of the total PCs is associated with DF fractions. Even so, in the case of papaya, it was found that in addition to bioavailability and bioaccesibility of its PCs, instability due to changes in $\mathrm{pH}$ is a factor to consider. Therefore, the exposure of the PCs to different $\mathrm{pH}$ conditions of the gastrointestinal tract represents a limiting factor in the use of its antioxidant properties.

\section{Acknowledgements}

We thank CIAD and CONACYT-México for financial support. This work is part of the projects "Nutrigenómica e interacciones moleculares de fenoles y fibra dietaria del mango "Ataulfo" (Mangifera indica L.) en un sistema Murino" Project 179574CB2012-01, and "Consolidación de las acciones de investigación, innovación y desarrollo tecnológico en alimentos funcionales y nutracéuticos: Fortalecimiento de las actividades vinculadas al desarrollo científico y tecnológico de alto impacto". No. U0003-2015-3.

\section{References}

Anson, N. M., Selinheimo, E., Havenaar, R., Aura, A.-M., Mattila, I., Lehtinen, P., Bast, A., Poutanen, K., \& Haenen, G. R. (2009). Bioprocessing of wheat bran improves in vitro bioaccessibility and colonic metabolism of phenolic compounds. Journal of Agricultural and Food Chemistry, 57(14), 6148-6155. http://dx.doi.org/10.1021/ jf900492h. PMid:19537710.

Arranz, S., Saura-Calixto, F., Shaha, S., \& Kroon, P. A. (2009). High contents of nonextractable polyphenols in fruits suggest that polyphenol contents of plant foods have been underestimated. Journal of Agricultural and Food Chemistry, 57(16), 7298-7303. http://dx.doi.org/10.1021/jf9016652. PMid:19637929.

Borel, E., Hostettler, F., \& Deuel, H. (1952). Determination of sugar with 3, 5-dinitrosalicylic acid and phenol. Helvetica Chimica Acta, 35(1), 115-120. http://dx.doi.org/10.1002/hlca.19520350116. 
Bouayed, J., Hoffmann, L., \& Bohn, T. (2011). Total phenolics, flavonoids, anthocyanins and antioxidant activity following simulated gastrointestinal digestion and dialysis of apple varieties: bioaccessibility and potential uptake. Food Chemistry, 128(1), 14-21. http://dx.doi. org/10.1016/j.foodchem.2011.02.052. PMid:25214323.

Brand-Williams, W., Cuvelier, M., \& Berset, C. (1995). Use of a free radical method to evaluate antioxidant activity. LWT-Food Science and Technology, 28(1), 25-30. http://dx.doi.org/10.1016/S00236438(95)80008-5.

Bravo, L. (1998). Polyphenols: chemistry, dietary sources, metabolism, and nutritional significance. Nutrition Reviews, 56(11), 317-333. http://dx.doi.org/10.1111/j.1753-4887.1998.tb01670.x. PMid:9838798.

Das, L., Bhaumik, E., Raychaudhuri, U., \& Chakraborty, R. (2012). Role of nutraceuticals in human health. Journal of Food Science and Technology, 49(2), 173-183. http://dx.doi.org/10.1007/s13197-0110269-4. PMid:23572839.

Dembitsky, V. M., Poovarodom, S., Leontowicz, H., Leontowicz, M., Vearasilp, S., Trakhtenberg, S., \& Gorinstein, S. (2011a). The multiple nutrition properties of some exotic fruits: biological activity and active metabolites. Food Research International, 44(7), 1671-1701. http://dx.doi.org/10.1016/j.foodres.2011.03.003.

Dembitsky, V. M., Poovarodom, S., Leontowicz, H., Leontowicz, M., Vearasilp, S., Trakhtenberg, S., \& Gorinstein, S. (2011b). The multiple nutrition properties of some exotic fruits: biological activity and active metabolites. Food Research International, 44(7), 1671-1701. http://dx.doi.org/10.1016/j.foodres.2011.03.003.

Escarpa, A., \& González, M. C. (2001). Approach to the content of total extractable phenolic compounds from different food samples by comparison of chromatographic and spectrophotometric methods. Analytica Chimica Acta, 427(1), 119-127. http://dx.doi.org/10.1016/ S0003-2670(00)01188-0.

Femenia, A., Sánchez, E., Simal, S., \& Rosselló, C. (1998). Effects of drying pretreatments on the cell wall composition of grape tissues. Journal of Agricultural and Food Chemistry, 46(1), 271-276. http:// dx.doi.org/10.1021/jf9705025. PMid:10554231.

Fogliano, V., Corollaro, M. L., Vitaglione, P., Napolitano, A., Ferracane, R., Travaglia, F., Arlorio, M., Costabile, A., Klinder, A., \& Gibson, G. (2011). In vitro bioaccessibility and gut biotransformation of polyphenols present in the water-insoluble cocoa fraction. Molecular Nutrition \& Food Research, 55(Suppl 1), S44-S55. http://dx.doi. org/10.1002/mnfr.201000360. PMid:21294250.

Friedman, M., \& Jürgens, H. S. (2000). Effect of $\mathrm{pH}$ on the stability of plant phenolic compounds. Journal of Agricultural and Food Chemistry, 48(6), 2101-2110. http://dx.doi.org/10.1021/jf990489j. PMid:10888506.

Gayosso-García Sancho, L. E., Yahia, E. M., \& González-Aguilar, G. A. (2011). Identification and quantification of phenols, carotenoids, and vitamin $\mathrm{C}$ from papaya (Carica papaya L., cv. Maradol) fruit determined by HPLC-DAD-MS/MS-ESI. Food Research International, 44(5), 1284-1291. http://dx.doi.org/10.1016/j.foodres.2010.12.001.

Hartzfeld, P. W., Forkner, R., Hunter, M. D., \& Hagerman, A. E. (2002). Determination of hydrolyzable tannins (gallotannins and ellagitannins) after reaction with potassium iodate. Journal of Agricultural and Food Chemistry, 50(7), 1785-1790. http://dx.doi. org/10.1021/jf0111155. PMid:11902913.

Hossain, M. A., \& Rahman, S. (2011). Total phenolics, flavonoids and antioxidant activity of tropical fruit pineapple. Food Research International, 44(3), 672-676. http://dx.doi.org/10.1016/j.foodres.2010.11.036.

Kanazawa, K. (2011). Bioavailability of non-nutrients for preventing lifestyle-related diseases. Trends in Food Science \& Technology, 22(12), 655-659. http://dx.doi.org/10.1016/j.tifs.2011.06.005.
Kristl, J., Slekovec, M., Tojnko, S., \& Unuk, T. (2011). Extractable antioxidants and non-extractable phenolics in the total antioxidant activity of selected plum cultivars (Prunus domestica L.): evolution during on-tree ripening. Food Chemistry, 125(1), 29-34. http:// dx.doi.org/10.1016/j.foodchem.2010.08.027.

Krook, M. A., \& Hagerman, A. E. (2012). Stability of polyphenols epigallocatechin gallate and pentagalloyl glucose in a simulated digestive system. Food Research International, 49(1), 112-116. http:// dx.doi.org/10.1016/j.foodres.2012.08.004. PMid:23028206.

Leifert, W. R., \& Abeywardena, M. Y. (2008). Cardioprotective actions of grape polyphenols. Nutrition Research, 28(11), 729-737. http:// dx.doi.org/10.1016/j.nutres.2008.08.007. PMid:19083481.

Leontowicz, H., Leontowicz, M., Jesion, I., Bielecki, W., Poovarodom, S., Vearasilp, S., González-Aguilar, G., Robles-Sánchez, M., Trakhtenberg, S., \& Gorinstein, S. (2011). Positive effects of durian fruit at different stages of ripening on the hearts and livers of rats fed diets high in cholesterol. European Journal of Integrative Medicine, 3(3), e169-e181. http://dx.doi.org/10.1016/j.eujim.2011.08.005.

Manach, C., Scalbert, A., Morand, C., Rémésy, C., \& Jiménez, L. (2004). Polyphenols: food sources and bioavailability. The American Journal of Clinical Nutrition, 79(5), 727-747. PMid:15113710.

Manach, C., Williamson, G., Morand, C., Scalbert, A., \& Rémésy, C. (2005). Bioavailability and bioefficacy of polyphenols in humans. I. Review of 97 bioavailability studies. The American Journal of Clinical Nutrition, 81(1, Suppl), 230S-242S. PMid:15640486.

Mañas, E., \& Saura-Calixto, F. (1995). Dietary fibre analysis: methodological error sources. European Journal of Clinical Nutrition, 49(Suppl 3), S158-S162. PMid:8549514.

Mertz, C., Gancel, A.-L., Gunata, Z., Alter, P., Dhuique-Mayer, C., Vaillant, F., Perez, A. M., Ruales, J., \& Brat, P. (2009). Phenolic compounds, carotenoids and antioxidant activity of three tropical fruits. Journal of Food Composition and Analysis, 22(5), 381-387. http://dx.doi.org/10.1016/j.jfca.2008.06.008.

Nantitanon, W., Yotsawimonwat, S., \& Okonogi, S. (2010). Factors influencing antioxidant activities and total phenolic content of guava leaf extract. LWT - Food Science and Technology, 43(7), 1095-1103. http://dx.doi.org/10.1016/j.lwt.2010.02.015.

Nohynek, L. J., Alakomi, H. L., Kähkönen, M. P., Heinonen, M., Helander, I. M., Oksman-Caldentey, K. M., \& Puupponen-Pimiä, R. H. (2006). Berry phenolics: antimicrobial properties and mechanisms of action against severe human pathogens. Nutrition and Cancer, 54(1), 18-32. http://dx.doi.org/10.1207/s15327914nc5401_4. PMid:16800770.

Palafox-Carlos, H., Ayala-Zavala, J. F., \& González-Aguilar, G. A. (2011). The role of dietary fiber in the bioaccessibility and bioavailability of fruit and vegetable antioxidants. Journal of Food Science, 76(1), R6-R15. http://dx.doi.org/10.1111/j.1750-3841.2010.01957.x. PMid:21535705.

Palafox-Carlos, H., Yahia, E., \& González-Aguilar, G. (2012a). Identification and quantification of major phenolic compounds from mango (Mangifera indica, cv. Ataulfo) fruit by HPLC-DAD-MS/ MS-ESI and their individual contribution to the antioxidant activity during ripening. Food Chemistry, 135(1), 105-111. http://dx.doi. org/10.1016/j.foodchem.2012.04.103. PMid:23017399.

Palafox-Carlos, H., Yahia, E., Islas-Osuna, M., Gutierrez-Martinez, P., Robles-Sánchez, M., \& González-Aguilar, G. (2012b). Effect of ripeness stage of mango fruit (Mangifera indica L., cv. Ataulfo) on physiological parameters and antioxidant activity. Scientia Horticulturae, 135, 7-13. http://dx.doi.org/10.1016/j.scienta.2011.11.027.

Pérez-Jiménez, J., \& Saura-Calixto, F. (2005). Literature data may underestimate the actual antioxidant capacity of cereals. Journal of 
Agricultural and Food Chemistry, 53(12), 5036-5040. http://dx.doi. org/10.1021/jf050049u. PMid:15941353.

Pérez-Jiménez, J., Serrano, J., Tabernero, M., Arranz, S., Díaz-Rubio, M. E., García-Diz, L., Goñi, I., \& Saura-Calixto, F. (2009). Bioavailability of phenolic antioxidants associated with dietary fiber: plasma antioxidant capacity after acute and long-term intake in humans. Plant Foods for Human Nutrition, 64(2), 102-107. http://dx.doi. org/10.1007/s11130-009-0110-7. PMid:19444613.

Porrini, M., \& Riso, P. (2008). Factors influencing the bioavailability of antioxidants in foods: a critical appraisal. Nutrition, Metabolism, and Cardiovascular Diseases, 18(10), 647-650. http://dx.doi.org/10.1016/j. numecd.2008.08.004. PMid:18996686.

Pozuelo, M. J., Agis-Torres, A., Hervert-Hernández, D., Elvira LópezOliva, M., Muñoz-Martínez, E., Rotger, R., \& Goñi, I. (2012). Grape Antioxidant Dietary Fiber Stimulates Lactobacillus Growth in Rat Cecum. Journal of Food Science, 77(2), H59-H62. http://dx.doi. org/10.1111/j.1750-3841.2011.02520.x. PMid:22224928.

Quintana, G., Rocha, G., Velásquez, J., Barbosa, A., Henao, E., Castro, C., \& Gonçalves, A. (2008). Influencia de factores de la reacción de oxidación de lignina sobre la adsorción de metales. Revista Investigaciones Aplicadas, (4), 16-22.

Quirós-Sauceda, A. E. (2012). Efecto de la presencia de fibra dietaria sobre el potencial antioxidante de los compuestos fenólicos de extractos de frutas tropicales (Master's thesis). Centro de investigación en Alimentación y Desarrollo, Hermosillo, Mexico.

Quirós-Sauceda, A. E., Ayala-Zavala, J. F., Sáyago-Ayerdi, S. G., Vélez-de La Rocha, R., Sañudo-Barajas, A., \& González-Aguilar, G. A. (2014). Added dietary fiber reduces the antioxidant capacity of phenolic compounds extracted from tropical fruit. Journal of Applied Botany and Food Quality, 87, 227-233.
Ragaert, P., Verbeke, W., Devlieghere, F., \& Debevere, J. (2004). Consumer perception and choice of minimally processed vegetables and packaged fruits. Food Quality and Preference, 15(3), 259-270. http://dx.doi.org/10.1016/S0950-3293(03)00066-1.

Ramulu, P., \& Rao, P. U. (2003). Total, insoluble and soluble dietary fiber contents of Indian fruits. Journal of Food Composition and Analysis, 16(6), 677-685. http://dx.doi.org/10.1016/S0889-1575(03)00095-4.

Re, R., Pellegrini, N., Proteggente, A., Pannala, A., Yang, M., \& RiceEvans, C. (1999). Antioxidant activity applying an improved ABTS radical cation decolorization assay. Free Radical Biology \& Medicine, 26(9-10), 1231-1237. http://dx.doi.org/10.1016/S0891-5849(98)003153. PMid:10381194.

Saura-Calixto, F. (1998). Antioxidant dietary fiber product: a new concept and a potential food ingredient. Journal of Agricultural and Food Chemistry, 46(10), 4303-4306. http://dx.doi.org/10.1021/jf9803841.

Saura-Calixto, F., García-Alonso, A., Goni, I., \& Bravo, L. (2000). In vitro determination of the indigestible fraction in foods: an alternative to dietary fiber analysis. Journal of Agricultural and Food Chemistry, 48(8), 3342-3347. http://dx.doi.org/10.1021/jf0000373. PMid:10956113.

Saura-Calixto, F., Serrano, J., \& Goñi, I. (2007). Intake and bioaccessibility of total polyphenols in a whole diet. Food Chemistry, 101(2), 492501. http://dx.doi.org/10.1016/j.foodchem.2006.02.006.

Singh, M., Arseneault, M., Sanderson, T., Murthy, V., \& Ramassamy, C. (2008). Challenges for research on polyphenols from foods in Alzheimer's disease: bioavailability, metabolism, and cellular and molecular mechanisms. Journal of Agricultural and Food Chemistry, 56(13), 4855-4873. http://dx.doi.org/10.1021/jf0735073. PMid:18557624.

Singleton, V. L., \& Rossi, J. A. (1965). Colorimetry of total phenolics with phosphomolybdic-phosphotungstic acid reagents. American Journal of Enology and Viticulture, 16(3), 144-158. 